\title{
Clash of Spheres - The Paradox of Being a Female Teacher in the Philippines
}

\author{
Roxanne T. Bongco \\ Bataan State Peninsula University, Manila \\ roxanne_bongco@yahoo.com \\ Rodrigo D. Abenes \\ Philippine Normal University, Manila \\ abenes.rd@pnu.edu.ph
}

\begin{abstract}
Feminisation in the teaching profession is a global issue. It has been said this problem implies gender inequality in relation to their male counterpart for it results in the lack of male models in the basic education and, thus promote social exclusion. This social reality is also the case in the Philippines. Data in 2008-2009 from the Philippine Commission on Women reveals that about $89.58 \%$ of the teachers in public elementary and $77.06 \%$ in the public secondary schools are female (PCW, 2014). In this regard, this paper argues that feminisation of education in the Philippines, all the more result to uncompromising situations of female teachers for as women, they need to work in shifts as part of their changing roles both in school and at home. Further, this paper presents an analysis of the narratives of ten female teachers in basic education which reveals that in spite of the feminisation of teaching from a purely statistical perspective, they still remain disadvantaged in the career that had always been believed to be their domain, especially in the area of career promotion. Limiting factors to the promotion of women still point to their social conditions as women, where the multiplicity of social expectations and duties in their diverse spheres clash to the detriment of their careers.
\end{abstract}

\section{Keywords}

feminisation - teacher education - changing gender roles - Philippines 
This paper serves as a two-fold response in feminist theorizing: first, as a positive response to Dela Cruz's (2017) article entitled 'Why Social Movement Need Philosophy' and second as a negative response to Ocay's work (2018) entitled 'Inclusion in Education'. It serves as a positive response to Dela Cruz because it deals with social struggles of women, as social struggle both in schools and homes. As such, it wanted to philosophize via using feminism as a way of critique towards the current state of Philippine educational system and thus can be extend to a more advancing political advocacy. Second, it is a negative response to Ocay because in his clamor for a gender-fair education, Ocay (2018) in his recent work, he claimed that, by looking at the sex-disaggregated data now in the "United Kingdom... where discrimination against women are not so pronounced," it is quite evident that the real victims of this gender inequality in education are the male students whose performance could be seen lagging behind the girls. Ocay blamed this underachievement of the male students to the feminisation of teaching (among other things), believing that due to the increasing number of women in the field of teaching, the curriculum, the instructional materials, and the structure of schooling itself becomes more favorable to the female students. Ocay further quoted Smith (2006) who believed that in our effort to achieve male and female equality... 'it has gone too far the other way.'

Now, this kind of trend in teaching is inarguable, as a worldwide trend could be gleaned from the World Bank data which shows a steady upward trend in the percentage of female teachers at the primary level. In fact, as of $2016,65 \%$ of the teachers at the primary level all over the world are women. According to Kelleher (2011) who cited the UNEsco's data on the percentage of female teachers in the primary and secondary education (respectively) in 2007, feminisation of teaching is very much evident in almost every region in the world including the Arab States (59/51); Central and Eastern Europe (80/ 74); Central Asia (86/69); East Asia and the Pacific (6o/ 48); Latin America and the Carribean (78/6o); and North America and Western Europe (85/61). The only exception would be the South and West Asian (45/36); and Sub Saharan African (44/30) regions. Similarly, in the Philippines, according to the Philippine Commission on Women (2014), as of 2008-2009, 89.58\% of the teachers in public elementary schools and $77.06 \%$ of the teachers in public secondary schools are females. This is an overwhelming majority. In fact, using the OECD standard which was also adopted by the UNESCO in its 2011 studies on the feminisation of teaching, the field could be categorized as highly feminised, from the statistical standpoint. 
However, it is curious, however, that in spite of the statistical dominance of the women in the field of teaching, their journey towards promotion in the career remains quite steep. In fact, Williams, as cited by N Ric18 \l 13321 (Rich 2018) claimed that men who do become teachers tend to be promoted more quickly into senior administrative positions. Similarly, in the Philippines, former CHED Commissioner, Patricia Licuanan said (during the 1oth National Conference this to last August 2018) that women are underrepresented in the top managerial positions. It is indeed quite curious how women would find it hard to ascend to the higher levels of her career in spite of the fact that teaching is believed to be her domain.

\section{$2 \quad$ Methodology}

It is within this context that we frame the problem that this paper intended to explore: "How does her gender roles affect the life of a female teacher?" And this question had been answered by looking into Her Story by looking at the narratives of ten female teachers. Specifically, this study employs a Narrative Inquiry Method which focuses on the participants' stories which have the power to make "the implicit explicit, the hidden seen, the unformed formed, and the confusing clear" (Atkinson, 1998, p. 7). Without imposing external restrictions, it is a method that encourages the participants to share their personal stories. Further, this methodology amplifies the unheard voices of the participants and thus communicate the realities of such participants to a wider audience. It also provides illumination of the participants as real people by 'painting' their lived stories, through which the researcher attempts to gain a deeper understanding. In contrast to the quest for objective and decontextualized truths, the purpose of using this methodology is to surface the meanings of the participants' lived experiences. Instead of predicting and explaining the world, this methodology allows the researcher to understand the world of the participants through their narratives (Wang \& Geale, 2015).

As such, ten teachers in Bataan, Philippines were interviewed individually for this study. Using purposive sampling to satisfy the requirements of the research, selection ensured that all teacher participants satisfy all of the following conditions: (1) married, (2) female teacher, (3) who had been teaching in basic education for seven years or more.

For a better analysis of the division of labor at home, the study also limits the research to the female teachers whose husbands have local employment and lives in the same house with them.

In Table 1 is the profile of the 10 female participants for this study. 
TABLE 1 Profile Of Respondents

\begin{tabular}{|c|c|c|c|c|c|}
\hline CODE & $\begin{array}{l}\text { YEARS } \\
\text { MARRIED }\end{array}$ & AGE & Rank & $\begin{array}{l}\text { YEARS IN } \\
\text { SERVICE }\end{array}$ & Target Career \\
\hline $\mathrm{P}_{1}$ & 19 & 46 & Teacher 3 & 23 & $\begin{array}{l}\text { Not sure about the } \\
\text { track }\end{array}$ \\
\hline $\mathrm{P}_{2}$ & 30 & $5^{8}$ & Teacher 2 & 32 & $\begin{array}{l}\text { Desired promotion } \\
\text { when younger. }\end{array}$ \\
\hline $\mathrm{P}_{3}$ & 18 & 49 & Teacher 3 & 9 & Master Teacher \\
\hline $\mathrm{P}_{4}$ & 4 & 31 & Teacher 1 & 10 & Master Teacher \\
\hline $\mathrm{P}_{5}$ & 26 & 55 & Teacher 3 & 35 & $\begin{array}{l}\text { Contented with the } \\
\text { current rank }\end{array}$ \\
\hline P6 & 20 & 37 & Teacher 2 & 13 & Master Teacher \\
\hline $\mathrm{P}_{7}$ & 15 & 43 & Head Teacher 3 & 17 & Principal \\
\hline P8 & 4 & 33 & Teacher 1 & 9 & Supervisor \\
\hline P9 & 16 & 43 & Teacher 3 & 22 & Master Teacher \\
\hline P10 & 32 & 54 & Master Teacher 2 & 32 & $\begin{array}{l}\text { Contented for now but } \\
\text { willing to be promoted } \\
\text { if there will be an } \\
\text { opportunity }\end{array}$ \\
\hline
\end{tabular}

The nature of the study was explained to the participants and their voluntary participation was sought. The interviews explored the stories in the different spheres in the lives of the female teachers, in order to determine the issues that encumber their professional growth and promotion. However, it is imperative for the researchers to set aside their preconceptions and prejudices to ensure that objective analysis would be made on the information that will be shared by the participants. Finally, themes were derived regarding the essence of shared experiences.

\section{Result of the Study}

After having interviewed the respondents, the researchers had found out three themes regarding the experiences of female teachers. These are the clash of spheres, the clash in their ideologies and the clash in her multiple shifts. 
Like every other profession in the world, teaching provides chances for teachers for professional growth through which a professional could be promoted to higher ranks within the education sector. This is a reward system that is being utilized by the management in order to motivate teachers to further improve their qualifications and performance. This promotion scheme is a very significant concern because this is the system by which the members of the profession would find their passage to desired wage, status, prestige, and power. And in a profession, such as teaching, promotion to higher ranks requires dedication of time and effort (Wong, 2009).

To guide such assent to the promotional hierarchy, the Department of Education have issued policies and guidelines that would ensure equal chances of every member of the profession to the said opportunities, regardless of their sexes. According to various orders of the Department of Education, points or credits for those who wish to apply for higher ranks in the field of education would be taken from the following: (1) educational attainment (such as master's and doctorate degree); (2) length of service in public and/or private school; and (3) professional activities such as seminars and trainings, research, presentations, publications, and the like. These schemes for promotion require the same qualifications for certain ranks that offer equal duties and responsibilities and equal pay for any qualified professional, whether he/she be a male or female.

Exploring their desire for promotion, the women assured us that they want to be promoted. During the course of the interviews surfacing all the challenges that they are currently facing and they expect to encounter in their career pursuit, the female teachers gave a very strong and determined response that they are willing to push through with this pursuit regardless of such challenges. One teacher said:

"Syempre naman (itutuloy ko). Ayoko naming tumanda na wala akong mararating. Ayoko namang tumanda na ganito na lang ang rank. (Of course, [I am willing to pursue it]. I don't want to age to I don't want to get older without achieving anything. I do not want to age in this rank.) (P6)."

However, it had been observed that, on many occasions, the participants tend to put off their pursuit for desired promotions, most especially during their children's growing years. Due to the challenging demands of balancing their productive employment with their roles as wives and mothers to young kids, female teachers often opt to delay their professional development. They only get the chance to return to the pursuit once the kids have already grown independent. 
This often intended only to be a temporary decision. However, the sad thing is that this temporary decision could make a long-lasting impact on their careers. This could be gleaned from the story of one teacher who had to let go of her desired position by way of considering the more pressing needs of her family at the time:

"Sa totoo, 'nun nabigyan ako ng pagkakataong magdepartment head. (Kaso) mababa ang sahod, e, MT (master teacher) na ako. Ginive way ko yun dahil mas mataas ang sahod ng MT. Ginrab ko yung pagiging MT kasi nagpapaaral ako ng mga anak... Ngayon... dumating yung time na stable na sila, gusto ko na maging head. Dumating ako sa puntong okay lang sa 'king i-give up ko yung sweldo ko (bilang MT) makuha ko lang yung posisyon na yon... (Truth is, I was once given the chance to become a department head. However, the salary was lower than what I was already earning as a Master Teacher. I gave way (the headteacher position) because MT offers better pay. I preferred the MT position because I was then sending my kids to school. Now that they (my children) are already stable, and I want to be head (teacher). I came to the point when I was willing to give up higher salary (as MT) just to get that position.) (P1o)"

And our quest for the roots of such delay took us to the clash of the various roles that they are playing in the different spheres of their lives. Because these women are more than just professionals. They are also mothers, wives, and even housekeepers. And more often than not, these roles make a lot of demands that often clash with each other. And much of these clashes are very much evident in their ideologies and in the actual tasks that they are performing which are highly characterized by multiple shifts.

The participants made it quite plain that the reason why they are working (as teachers) is because of their families. They all agree that both the family and work are important, which is why they need to balance these two. However, if the demands in their work would affect their obligations as mothers and wives at home, they would be willing to sacrifice their careers just to ensure that their roles at home would be taken cared of.

"Kapag may sakit ang anak, hindi ako pumapasok dati. Kasi kaya tayo nagtatrabaho para sa pamilya e.... Family muna. Kaya tayo nagtatarabaho 
para sa pamilya e. (In the past, whenever my kids were sick, I would not go to work. After all, the reason we work is the family. Family first. They are the reason why we are working.) (P10)"

"Kailangan balansehin mo ... Ngayon. kung mapapabayaan ang mga anak, igigive way ko yung career... Ngayon, okay naman, pero kung sila ang magsasakripisyo para sa akin, hindi pwede. (You would have to balance. But I would happen to neglect my kids due to work, I would sacrifice my career. Now, we are okay. But if the kids would be required to sacrifice for me, I would not let that happen.) ( $\left.\mathrm{P}_{7}\right)$."

"Pero mas importante pa rin kasi ang family ko. Ang ministry mo kasi, unang una, pamilya e. (Family is more important to me because your first ministry is the family.) (P8)"

Indeed, Filipinos valued family life as something central to their universe (Jocano, 1998), as cited by (Macapagal, Ofreneo, Montiel, \& Nolasco, 2013) to Indeed, Filipinos valued family life as something central to their universe (Jocano, 1998). Similarly, in the study of Bulatao $(1963,1992,1998)$, the family is one of the four values shared by Filipinos. It is a norm that sacrifices would have to be made (if needs are) for the betterment of the family. Parents are expected to strive hard to provide for the kids. Further, that mothers would sacrifice for the family is part of that norm (Macapagal, Ofreneo, Montiel, \& Nolasco, 2013).

As the promotion to higher ranks is connected with certain demands (such as time, extended duties, and finances) that often clash with the concerns of the family, this places the female teachers in a dilemma where they would have to choose between their career pursuit and the family. And with this ideology about the family, the choices are often in favor of their roles at home.

One major concern that compels female teachers to put off their pursuit of promotion is the financial consideration. Some of the sources of points or credits for promotion in the profession include trainings and graduate studies. While the Department of Education provides in-service training for the teacher, those who aspire for higher positions might still need to invest in their own trainings and seminars. Moreover, further studies (graduate studies), which is another significant consideration for promotion also entails financial tension that often places teachers in a difficult position of having to choose priorities.

Interviews with the participants reveal that in most cases, the reason why many teachers still haven't completed their master's degree is due to financial constraints. The needs of the children and of the whole family would always be prioritized over the tuition fee needed for graduate studies. As such, they require a longer time to save sufficiently to pursue their continuing education. 
"Number one is expenses kasi yung anak ko college na, engineering yun. Hindi ko alam ngayon kung anong mga darating na gastos. Baka masabay sa kin. (Number one (consideration) is the expenses, especialy because my kid is taking an engineering course now. I could not predict the possible expenses. What if it coincides with the demands of my own studies?) (P6)."

As for participants who are driven to pursue career promotion, they were certain that if they would have to sacrifice anything in order to achieve their desired promotion, it would certainly be not their families, much less the children. As such, they would much rather sacrifice their time for themselves rather than allow their careers get in the way of their roles at home.

"Kung mag-uuwi ng trabaho sa bahay, hindi maapektuhan ang oras sa mga anak namin. Gagamitin namin (ng asawa na guro din) yung alanganing oras na tulog na sila (mga bata). (If ever we would have to take home some of our work from school, it would not affect our time for the kids. We (husband is also a teacher) will use the time when the kids are already sleeping.) ( $\left.\mathrm{P}_{7}\right)$."

Difficult as it may be, these are natural sacrifices that female married teachers are compelled and expected to make, more because of the internal control mechanisms which are connected to their concept of self.

As was asserted by Pena-Alampay, (2013), with their interdependent conception of self Filipinos create their concept of self in relation with kapwa (which pertains to the unity of self and others, in contrast to the English term of others which is the opposite of self). This provides a Filipino to view him/ herself in relation to others, (Macapagal, Ofreneo, Montiel, \& Nolasco, 2013), particularly with the family. Moreover, other people's perception of an individual has a significant effect on how the person would see him/herself which was described by Charles H. Cooley in a phenomenon called looking-glass self (Macapagal, Ofreneo, Montiel, \& Nolasco, 2013). However, with people's perception of others being guided by ideologies which had been institutionalized in a certain class or culture, these ideologies make a terrible impact on their course of actions and decisions.

As such, the standards that the society is using to judge her as an individual matter a lot to a Filipino woman. It is therefore important to her that in the society's standards, earning for the family is the responsibility of the male and child-rearing and making of the home is the duty of the woman (Angeles, 1994). 
This is what makes this difficult decision seem so natural for these female Filipino teachers. As her identity as a mother and wife is more basic to her concept of 'self' over her identity as a professional in the productive world, the woman would much rather be a "less committed professional" than an "irresponsible mother and/or wife," because that is less detrimental to her identity of self.

Almost all of the participants who were interviewed shared that they have other designations, in addition to their basic responsibilities as teachers and/ or class advisers. This includes being a manager of the canteen, trainer during various competitions, coordinators for events and programs, property custodian, club adviser, among others. This, multiple roles, however, is only a description of their role as professionals.

In addition to these tasks as professionals, once the teachers go home, they take their second and third shifts as mothers and/or wives. It had been observed that many of the female teachers who had been interviewed claim responsibility for the household chores. In inquiring regarding their tasks from sunrise to sunset, it appears that it is still the women who have the main responsibility for household chores and taking care of the family. This includes cooking the meal for the family, cleaning the house, ironing the clothes, taking care of the kids, among others. According to one of the participants:

“...pahinga ko, laba... (rest for me equates laundry...) $\left(\mathrm{P}_{7}\right) . ”$

In English, it could be understood as a metaphorical “I don't even get to rest." Another participant jokingly described herself as:

"Pag dating sa bahay, katulong. Pag dating sa school, titser. (I'm a maid at home and teacher in school) (P6)."

Further, it had been observed that the participants have the notion that no one else but they would perform such duties. No one, according to them, would be carrying on the tasks at home if they are unavailable or not around (e.g. due to seminars). In cases when they have urgent tasks at school that they would need to take home, they could postpone some of the tasks. However, the participants emphasized that after their urgent work demands, they would still be the one to carry on the duties that they postponed at home. This is true even 
in some cases where both the wife and husband who works in the productive sphere.

This is possibly one of the reasons why many of the female teachers are very hesitant to take part in seminars and training programs which sometimes require them to be away from home for days.

"Usually ang pinakamaikling seminar na kinocunduct ng DepEd, three days. Imaginin mo, three days akong wala sa bahay. (The shortest seminar that DepEd usually conduct is about three days. Could you imagine? I'd be away from home for three days.) ( $\left.\mathrm{P}_{3}\right)$."

These are the multiple duties that married female teachers are expected to carry on each day. In addition to being a professional who earns for the family, they have three more roles to carry on each day- that of a housekeeper, a mother to the kids, and wife to the husband (Honculada, 1994). Abenes also wrote something along the same line. Due to the emergence of capitalism, women were compelled to work in shifts: Shift 1: as a worker in the productive sphere; Shift 2 and 3: as wife and mother in her domestic sphere (Abenes, 2015).

Abenes further explained that even prior to marriage, the Filipinas were already trained to be a good wife which means a lot of things. She will be the 'Ilaw ng Tahanan' who shall take care of the kids, the family budget, and take charge of the household tasks such as cooking, cleaning, laundry, among many others. This is in support of the husband who shall be the 'Haligi ng Tahanan,' providing for the family financially (Abenes, 2015).

This is the manifestation of the allocation of work in the capitalist society where there are two spheres: the public and the domestic reproduction. The market or economic production had been largely controlled by men, while the domestic reproduction which is of two kinds (replenishing people through sustenance and rest, and childbearing and rearing) is considered the domain of woman (Angeles, 1994). Although the wife could enter into a paid work, it is her choice. However, it is not considered a necessity because her primary responsibility is at home (Honculada, 1994). In addition, providing for the family is the primary duty of the man, and therefore, her earning is only seen as an addition to the family earnings. This perpetuated to the neocolonial period which brought about a new social structure where the goal is not the reproductive but the paid work in the public sphere. This, in turn, resulted in the reallocation of work in the family (Eviota, 1993), as cited by (Abenes, 2015). However, in spite of the movement of the women to the productive sphere, the expected comparable movement of men to the domestic work seemed absent 
(Honculada, 1994). No longer confined to domestic reproductive work, women now have to play the role in multiple shifts.

Taxing as it may be for the woman, the male did not initially see the need to take his share of the domestic work, as she enters the paid work, due to the notion of work that was instilled by the capitalist society. Work being equated to an activity which yields cash income (Angeles, 1994), domestic reproduction had been devalued for the longest time.

Nonetheless, rising consciousness on the concern over women's multiple shifts, more and more men are now taking their share in the domestic labor. In fact, men are now spending less time in productive work and more in home production which somehow equates to a better condition for women (Stevenson \& Wolfers, 2008).

In fact, one of the participants explained that most of the work at home is taken cared of by the husband who is also a teacher like herself, and she takes charge of attending to the needs of their newborn before they leave the child to her mother:

"Mabait siya. Siya yung naglalaba, naglilinis. Pagluluto lang yung hindi. Yung mother ko ang nagluluto sa amin. (He is kind. He does the laundry and cleaning, except cooking. My mom does the cooking for us.) ( $\left.\mathrm{P}_{4}\right)$ "

In other cases, the husband shares with the tasks at home, most especially if both of them (husband and wife) have their productive work. However, their ownership of the responsibility could still be observed, in spite of the division of labor.

"Kahit gawaing pambabae minsan, tinutulungan niya pa rin ako. (He still helps me even if it is woman's task.) (P9)."

It would be observed how the woman regards the participation of the man as help/ assistance only, while the major responsibility lies with her as a female. This is because the idea is deeply ingrained in the consciousness of the women that domestic work is their responsibility, regardless of their participation in the public sphere (Anonuevo, 1994).

One of the possible consequences of this in women's well-being was discussed in the paper of Stevenson \& Wolfers, (2008), 'The Paradox of Declining Female Happiness.' It was indeed ironic that in spite of the increased social and economic opportunities for women in the era, women in the US have become less happy both absolutely and relatively to men. One of the possible explanations that the researchers see is the effect of the changes in the role of 
women in the measures of subjective well-being. Changes in their roles have caused women to equate satisfaction not only to one role but to, multiple roles that she has to play. For instance, in the past, satisfaction only meant "satisfaction at home." But with the multiplicity of her role now in both spheres, she is considering "satisfaction at home" as well as "satisfaction at work." The challenge in achieving the same level of happiness or satisfaction at multiple domains leads to lower average satisfaction.

\section{Conclusion}

Feminisation in the teaching profession is a global issue. It has been said that this problem implies gender inequality in relation to their male counterpart for its results in the lack of male models in the basic education and, thus promote social exclusion. However, while it is often perceived as the seeming domination of women in the career, it could be historically gleaned how feminisation of teaching came about as the result, not of women empowerment, but of men's domination.

LeQuire (2016) explained how the seeming dominance of women in the profession is rooted in historical economic conditions and gender beliefs. LeQuire wrote that prior to $185 \mathrm{os}$, the majority of the teaching positions were held by men which changed dramatically in the 19th century due to the industrialization which directed men to the new paths of business and more money. These include trade in the stock market, work in railroads and factory management. This abundance of new opportunities for men left many of the teaching positions vacant which was later occupied by women who could be paid less.

Further, Catharine Beecher also insisted that women are better suited in the teaching positions as compared to men pointing to the higher capability of the females to engage in human development work and willingness to make necessary sacrifices. Hoffman wrote that Beecher also asserted that teaching is an extension of maternal duties and could be a good alternative to marriage for single educated women (LeQuire, 2016).

LeQuire, however, believes that apart from her concern for learner development, Beecher's motives also include giving women better opportunities to hold "high and honorable profession" which could address the economic vulnerability of women in the 18 oos. Due to the limited economic opportunities available for women at that time, in spite of the depressing condition in the career, many females still flocked to the teaching profession due to its promise of independence and purpose. 
Around the 2oth century, the majority of the teaching position in America were held by women, although administrative positions were dominated by men, in addition to the meager salary and benefits that are seemingly absent. As such, 1890 's to 1910 gave rise to teachers' movements which gained success as evidenced by increased wage and women rising to higher positions of principals and superintendents.

Filipino formal educational system being patterned from the United States, these conditions of female teachers had similarly been passed on and perpetuated in the Philippine educational system. At present, even if the profession has improved greatly over time, it remains widely considered as a "woman's work" which is often equated to less prestige and less pay. In fact, Licuanan (2018) believed that one of the problems in higher education is the devaluation of the field as the number of women increases. A clear evidence to this is the continued blaming of the underachievement of male students to the feminization of teaching (as cited initially from the discussions of Ocay), in spite of the multiplicity of empirical evidence disproving the argument that male teachers bring out the best in the boys and vice versa. To cite a few, Lahelma's study in Finland (2000) shows that high school students do not give much importance to their teachers' genders; Butler and Christiansen's (2003), the study of undergraduate teaching showed that the gender of teaching assistant makes no significant and consistent effect on the actual performance of the students; and Ehrenberg, Goldhaber \& Brewer's (1995) study in the US found that matching of teachers and learners based on their gender and ethnicity does not have any significant effect on the student's educational achievements (Carrington, Tymms and Merrell 2005).

Abenes (2015) asserted, that as a human being, a woman also has pursuits in life. Not only does she need to survive, she also needed capital and wanted prestige. And the historical male domination which has a larger control over the economic production pushed her to the lower paying, less prestigious, and more 'self-sacrificing' careers such as teaching. This male domination is what brought about the feminisation of the teaching profession. Ever, this is not only a thing of the past, as these conditions still hold the power to shape women's career chances as was revealed in the narrative of the ten female teachers. Today, even in the perceived domination of women in the teaching career, analysis of the narratives of the ten married female teachers reveal that their gendered position in their life spheres still places women in an uncompromising situation. So that, in spite of the equal promotion schemes in the profession, these pervading conditions still work at the women's professional and economic disadvantage. 
At this point, much of the policymakers are showing concern on the feminisation of teaching, as men are being regarded as the dying breed in education. While this initiative must have emancipating value in itself, it has to be asserted that we have to look beyond the superficial details of the percentage of men and women in teaching. We have to scrutinize, as well the power struggle in the career so as to render genuity to our equality endeavors. For indeed, promotion for gender equality must go both ways. If we are to be concerned about the feminization of teaching, we should be just as concerned about the masculinization of the educational leadership (Drissen 2007).

We would like to believe that policy-wise, the Philippines is already one of the most egalitarian societies in the region, if not the world, especially with the passing of the Magna Carta of Women and the general appropriations of a fund specifically for gender equality endeavors. And for its part, the sector of education is promoting an equal scheme of promotion to allow fair chances for all members of the professional regardless of their sexes. Nonetheless, we believe that in spite of the intended 'fairness', this scheme still misses on something. It misses on the reality that because of their gender roles in the society, male and female teachers are standing on two unequal levels, to begin with, so that in spite of such fair scheme, inequality is still on the ground. Be considered that these married female teachers are more than just professionals. They are also mothers and wives. They take various shifts in the multiple spheres that they live in and each of these roles makes certain demands. However, the demands of these spheres often clash to the detriment of another. And looking at the gendered identity of a Filipino woman, it is quite plain which one would be relegated to a higher priority and which would have to take the backseat. In the 1987 Philippine Constitution, the state made two prominent provisions in recognition of women's role in the country. In the Declaration of Principles Article II, Section 14 it asserted that: "The State recognizes the role of women in nationbuilding and shall ensure the fundamental equality before the law of women and men." Further, Article XIII-Labor: Section 14 provided that "The state shall protect working women by providing safe and healthful working conditions taking into account their maternal functions..." Nonetheless, these schemes have seemingly missed that in the Philippines, maternal functions go beyond childbearing. It goes to include child rearing and the making of the home.

While the sector of education responds to these principles with schemes of promotion that demands equality, the history and reality of women's condition in the society have made it quite plain that equity more than equality is required. For indeed, in spite of the statistical dominance of women in the field of teaching, they are still disadvantaged in the profession which is believed to be their domain. Limiting factors to the promotion of women still 
point to their social conditions as women, where the multiplicity of social expectations and duties in their diverse spheres clash to the detriment of their careers. Unless these realities are, therefore, considered in policy development in the sector such as in the teacher's workload and performance evaluations that provide important passage to their career promotion, their capability to contribute to the society to their full potential will ever be just a myth.

\section{References}

Abenes, Rodrigo. (2015). "The Genealogy of Male Domination in the Philippines." Baybayin, 23-36.

Angeles, Leonora C. (1994). "The Sexual Division of Labor." In Sex and Gender in Philippine Society, by Elizabeth U. Eviota, 115-138. National Commission on the role of Filipino Women: Manila.

Añonuevo, Carlos Antonio Q. (2010). An Overview of the Gender Situation in the Philippines. Friedrich-Ebert-Stiftung Philippine Office.

Añonuevo, Carolyn Medel-. (1994). "Ideology and Cultural Practice." In Sex and Gender in Filipino Society, by Elizaneth Eviota, 35-49. Manila: National Commission on the Role of Filipino Women.

Ang 1987 Konstitusyon ng Republika ng Pilipinas. (May 5, 2018). http://www.seasite.niu .edu/tagalog/ang_1987_konstitusyon_ng_republi.htm.

Ariogula, Sibel, and Nilufer Cana. (2010). "Teaching is a female profession in the eyes of a beholder' or is it?" Procedia, 629-633.

Carrington, Bruce, Peter Tymms, and Christine Merrell. (2005). "Role Models, school imporvement, and the gender gaps- Do men bring out the best in boys and women the best in girls?" EARLI 2005 Conference, Universty of Nicosia.

Dahle, Rannveig. (2012). "Social work: A history of gender and class in the profession." Ephemera, 309-326.

Dela Cruz, Noelle Leslie. (2017). "Why Social Movements Need Philosophy?" Kritike:An Online Journal of Philosophy, Volume 11 Number 1 June, 1-9.

DepEd. (2017). "DO 42, s. 2017 - National Adoption and Implementation of the Philippine Professional Standards for Teachers".

Drissen, Gert. (2007). "The Feminization of Primary Education: effects of Teachers sex on Pupils' Achievements, Attitudes, and Behaviors." Review of Education, 183-203.

Global, Campaign for Education. Gender Discrimination in Education: The Violation of Rights of Women and Girls. South Africa: Global, Campaign for Education, 2012.

Honculada, Jurgette. (1994). "The Family Household." In Sex and Gender in the Philippine Society, by Elizabeth U. Eviota, 83-110. Manila: National Commission on the Role of Filipino Women. 
Ke, Fengfeng, and Alison Carr-Chellman. (2006). "Solitary Learner in Online Collaborative Learning: A disappointing experience." The Quarterly Review of Distance Education, 249-265.

Kelleher, Fatimah. (2013). Women and the teaching profession. Commonwealth Education Partnerships 2012/13.

Kelleher, Fatimah, et al. (2011). Women and the Teaching Profession: Exploring the Feminisation Debate. London: Commonwealth Secretariat and UNESCo.

LeQuire, Shelby. The history of women as teachers. May 4, 2016. http://www.thewesterncarolinajournalist.com/cgi-sys/suspendedpage.cgi.

Licuanan, Patricia. (2018). "Gender Fair Education." 1oth National Conference, Women and Gender studies Association of the Phlippines, Inc ... Ateneo de Manila University, August 23.

Llego, Mark Anthony. (2016a). Criteria for Master Teacher. March 29. https://www .teacherph.com/criteria-master-teacher/.

Llego, Mark Anthony. (2016b). Guidelines in the Processing of Master Teacher I and II Documents. March 14. https://www.teacherph.com/guidelines-processing-master -teacher-documents/.

Llego, Mark Anthony. (2016c). Requirements Checklist for Reclassification to Master Teacher I/II Position. March 14. https://www.teacherph.com/requirements-checklist -for-reclassification-to-master-teacher-position/.

Llego, Mark Anthony. (2016d). Requirements Checklist for Head Teacher I, II, III in the Secondary Schools. January 10. https://www.teacherph.com/requirements-checklist -for-head-teacher-secondary-schools/.

Macapagal, Ma. Elizabeth j., Mira Alexis P. Ofreneo, Cristina J. Montiel, and Jocelyn M. Nolasco. (2013). Social Psychology in the Philippine Context. Quezon City: Ateneo De Manila University Press.

National, Commission on the Role of Filipino Women. (2006). CEDAW: Factsheet on Filipino Women. Manila City: National Commission on the Role of Filipino Women.

Ocay, Jeffry. (2018). Inclusion in Education: How Can Schools Ensure Equal Opportunity in Education. January 1. http://philonotes.com/index.php/2018/o1/o1/inclusion -in-education/.

Pereira, C.M. (2013). (En)Gender(ing) Complexities, Contradictions, and Multiplicities: My (A Researcher's) Feminist Poststructural Stories of/for Teaching Gender and/within Multicultural Teacher Education. A Dissertation. Michigan State University.

Peto, Andrea. (2012). Rethinking gender equality in the teaching profession: is secondary school teaching 'women-friendly'. June 5. http://www.genderandeducation.com/ issues/rethinking-gender-equality-in-the-teaching-profession-is-secondary-school -teaching-women-friendly/.n.d.

PCW. (2013). Filipino Factsheet. Manila: Philippine Commission on Women. 
PCW. (2018). Philippine Commission on Women. May 15. http://pcw.gov.ph/statistics/ 201405/statistics-filipino-women-and-mens-education.

RCTQ, Philippine National Research Center for Teacher Quality. Philippine Professional Standards for Teachers. Department of Education, 2016. n.d.

Rich, Motoko. (2018). Why Don't More Men Go Into Teaching?July 3. https://www.nytimes .com/2014/09/07/sunday-review/why-dont-more-men-gointo-.

Stevenson, Betsey, and Justin Wolfers. (2008). "The Paradox of Declining Female Happiness."

Sultana, A.M., Norhirdawati M Zahir, and Norzalan H Yaacob. (2014). "Women in the Teaching Profession: Impacts and Challenges." International Journal of Humanities and Social Sciences, 1694-1697.

Terrill, Alexandra L., John P. Garofalo, Elizabeth Soliday, and Rebecca Craft. (2012). "Multiple Roles and Stress Burden in Women: A Conceptual Model of Heart Disease Risk." Journal of Applied Biobehavioral Research, 4-22.

Ullah, Hazir. "School Teaching as a feminine profession: the legitimization and naturalization discources in pakistani Context." n.d.: 1-9.

Wang, Carol Chunfeng, and Sara Kathleen Geale. (2015). "The power of story: Narrative inquiry as a methodology in nursing research." International Journal of Nursing Sciences, $195^{-198 .}$

Wong, Ping-Man. (2009). "Teachers and Promotion: Research Evidence on teh Role of Gender, Career Intentions, Promotuon Criteria and Teacher satisfaction." International Handbook on Research on Teachers and Teaching, 511-523. 